\title{
Inside the Black Box of the Board: Towards a Global Comparative Model of Board Effectiveness for Listed Companies
}

\author{
Peter AM Jansen ${ }^{1, *}$ \\ ${ }^{1}$ Chemin de St. Jean 900, 06620 Le Bar sur Loup, France \\ *Corresponding author: Chemin de St. Jean 900, 06620 Le Bar sur Loup, France. Tel. \\ 33-673-300-881. E-mail: peter.jansen@1sbf.org.uk
}

Received: December 24, 2018 Accepted: January 25, 2019 Published: April 2, 2019

doi: 10.5296/jcgr.v3i1.14108ＵRL: https://doi.org/10.5296/jcgr.v3i1.14108

\begin{abstract}
This conceptual research seeks to develop a global comparable model of board effectiveness for listed companies based on a multi-theoretic and multi-disciplinary approach and mostly quantifiable macro-level (national culture and legal-institutional indicators) and micro-level variables (board characteristics and board processes), by synthesizing recent corporate governance theories on boards of directors and board effectiveness into a new theoretical model. In contrast to most existing models of board effectiveness, it accounts for the moderating effect of national contexts, the mediating influence of board roles on board processes, the relevance of those board processes as predictors of board effectiveness and it offers a validated board effectiveness measure that is directly linked to firm performance. Additionally, it offers a research strategy for cross-national board effectiveness research.
\end{abstract}

Keywords: Corporate governance, board effectiveness, board characteristics, board processes, board roles, legal-institutional indicators, financial-economic factors, national culture (work-related values) 


\section{Macrothink}

\section{Introduction}

The importance of corporate governance has grown steadily over the past 15 to 20 years, especially after the high-profile corporate scandals surrounding the downfall of Enron, or more recently, Lehmann Brothers. These scandals have contributed to a loss in investor and public confidence in corporations and concerns over the integrity of the key actors in the economic arena (Solomon, 2013).

However, there is no generally agreed definition of corporate governance and board effectiveness. Corporate governance and board effectiveness have been approached from many different angles, ranging from financial-economic, social psychology, management theory to sociology. This has resulted in a lack of shared definitions and theoretical paradigms, making comparison and empirical progress difficult. In keeping with increasing demands for a multi-theoretic approach (e.g. Nicholson and Kiel, 2004; Aguilera, 2005; Huse, 2005), this research tries to bridge this gap by developing a multi-disciplinary and multi-theoretical approach to board effectiveness.

According to Solomon (2013) there are basically two opposing views on corporate governance (see Figure 1). The 'narrow' or financial view limits corporate governance to the relations between a company and its investors (shareholders). This view is known as 'agency theory', where the agent (manager) is representing the owner (principal). It tends to see agents as individualistic, opportunistic, and self-serving (Jensen and Meckling, 1976).

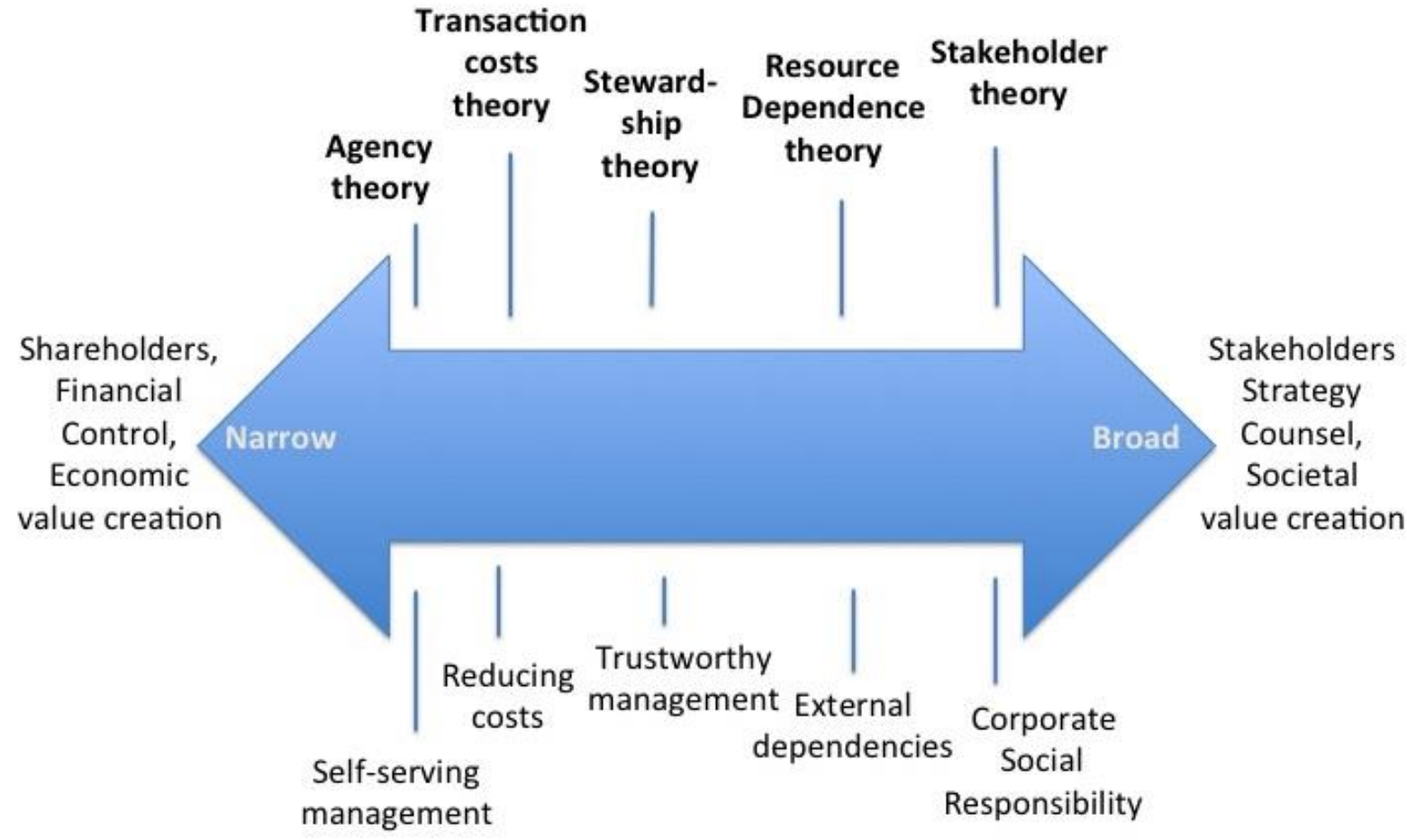

Source: The author

Figure 1. Theories of Corporate Governance 
The 'broad' or stakeholder view ((Blair, 1995; Clarke, 1998) on the other hand sees corporate governance as a myriad of relationships between a company and a wide range of stakeholders, ranging from clients, suppliers, employees, shareholders to government institutions and the local community. It has gained traction in recent years, as accountability and corporate social responsibility are becoming more important against the backdrop of recent corporate scandals.

This study follows an inclusive and broad view, in line with increasing calls for a multi-theoretic approach (e.g., Aguilera, 2005; Huse, 2005; Nicholson \& Kiel, 2004), in which corporate governance uses systems to guarantee that managers balance the interests of all its stakeholders, and that those stakeholders act responsible with regard to the resources invested in the firm (Aguilera, Filatotchev, Gospel, \& Jackson, 2008).

One of the key questions in corporate governance is what makes a board of directors effective (Petrovic, 2008). There is still limited evidence on what constitutes board effectiveness, notwithstanding the existence of a large pool of corporate governance literature. Board effectiveness has traditionally been linked to the concept of board independence, which is largely derived from agency theory (Solomon, 2013). It assumes that non-executive directors are able to influence top management and organizational decision-making, and thus have an impact on company performance. More recently, Abatecola, Farina and Gordini (2014) found that board independence enhances the performance of companies who are in crisis.

In many of the earlier studies, firm performance is used as a proxy for board effectiveness (e.g. Fama \& Jensen, 1983; Daily \& Johnson, 1997; Shleifer \& Vishny, 1997; Daily, Dalton and Canella, 2003; Johnson, Ellstrand, Dalton and Dalton, 2004). They mostly use quantitative methods to measure the relationships between board characteristics (like board size, board composition, non-executive ratio, CEO-Chair duality or director shareholding) and different financial performance metrics such as Return on Equity (ROE), Return on Assets (ROA), Earnings Per Share (EPS) and Tobin q (e.g. Zahra and Pearce, 1989; Yermack, 1996).

However, most empirical research on the relationship between board characteristics and firm performance has been at best inconsistent (Abdullah \& Page, 2009; Lawal, 2012). As Hermalin \& Weisbach (2003) mention, firm performance calculated in terms of accounting or economic measures is likely to be a combination of many different factors (such as economic situation, market developments or competitive pressures), and board task performance is only one of them.

So far, no single board effectiveness measure has yet emerged (Zona \& Zattoni, 2007). However, there is a growing consensus among researchers that a clear appreciation of the role of boards is essential to generating board effectiveness (Aguilera, 2005; Aguilera et al., 2008; Huse, 2005 \& 2007). Derived from this strain of literature, this study acknowledges that board effectiveness is determined by the board's ability to successfully carry out their control and service roles.

The focus of this board effectiveness study will be on listed companies in order to increase 
cross-country comparability and create a more balanced level playing field. Firstly, there are more publicly available data available about listed companies due to disclosure requirements, making cross-country comparison more feasible. Secondly, in many countries voluntary codes of corporate governance have become subject to capital market mechanisms and are sometimes even preconditions for stock market listing, making them quasi-mandatory (Braendle \& Noll, 2006), which further increases their comparability. Lastly, listed companies' behaviour will often influence privately owned companies and ultimately set a country's corporate governance standards (Aguilera \& Cuervo-Cazurra, 2009).

\section{Towards a Global Model of Board Effectiveness}

In this section the most important micro- and macro-level determinants of board effectiveness will be discussed and ultimately morphed into a comprehensive and comparable global model of board effectiveness, including a unique board effectiveness measure.

\subsection{Board Characteristics}

As discussed in the previous section, board effectiveness research has been mainly focused on the direct influence of quantitative board characteristics such as board size or number of non-executive directors on board effectiveness (e.g. Fama \& Jensen, 1983). It was also established that most empirical research on the relationship between board characteristics and firm performance has been mostly incongruent (e.g. Hermalin \& Weisbach, 2003).

However, in the case of cross-national analysis there is sufficient reason to include key board characteristics. Firstly, countries are usually at very different development stages in terms of corporate governance implementation and certain board characteristics such as number of non-executive directors might explain some of these differences. Secondly, countries are also very different in terms of history and culture, and board characteristics such as average age and gender of board members might be affected by cultural differences. Thirdly, the number of foreigners in the board (nationality) might be relevant, as it can influence the dominant work-related values (national culture) and board processes.

Lastly, board characteristics are excellent control variables, as is shown by Farquhar (2011) and Minichilli, Zattoni, Nielsen and Huse (2012) and can help explain some of the differences in terms of board processes, the main focus of this research. Control variables are usually variables the researcher is not primarily interested in, but which might have an effect on the dependent variable (i.e. board effectiveness) that the researcher wants to eliminate (Saunders, Lewis, \& Thornhill, 2012).

This research will primarily focus on seven widely researched key board characteristics. Four of them, namely board size, non-executive ratio, CEO/Chairperson duality and director shareholdings are in line with recent empirical studies focusing on board processes (Farquhar, 2011; Minichilli et al., 2012). Additionally, it is suggested to add board composition (age, gender, nationality) to the equation. According to an increasing body of academic literature, boardroom diversity is considered a driver of board effectiveness, creating greater diversity in 
perspective, knowledge, skills, experience, gender, nationality and age of non-executive directors and reducing the risk of 'group think' (e.g. Conger \& Lawler, 2001; Lückerath-Rovers, 2013; Solomon, 2013). This study focuses on the three most quantifiable elements of board composition, namely gender, age and nationality. Average age and gender (male/female ratio) of board members are relevant, as countries have different historical and cultural backgrounds which could influence these ratios, while nationality is important in the light of national cultural differences.

\subsection{Board Processes}

Several authors have developed input-process-output (I-P-O) models that try to include process variables as determinants of board effectiveness. In this social systems approach, they take a more holistic view of the board as a group of individuals and believe that agency theory models of corporate governance fail to capture the complexities of board dynamics (e.g. Forbes \& Milliken, 1999; Nicholson \& Kiel, 2004; Levrau \& Van den Berghe, 2007; Farquhar, 2011; Minichilli et al., 2012).

Especially Forbes and Milliken's (1999) seminal work on boards as strategic decision-making groups has been instrumental in putting actual board processes to the forefront of corporate governance research. More recently, Farquhar (2011) and Minichilli et al (2012) have empirically shown that board processes are better predictors of board effectiveness than board characteristics.

Other terms commonly used for board process are board conduct or board dynamics and are mostly extracted from the input-process-output (I-P-O) approach used in organizational small team studies (e.g. Hackman and Morris, 1975; Cohen and Baily, 1997; Marks, Mathieu, Zaccaro, 2001). Marks et al. (2001; p. 357) define team processes as "Members interdependent acts that convert inputs to outcomes through cognitive, verbal, and behavioral activities directed toward organizing task work to achieve collective goals". This definition is particularly useful as it links inputs (board characteristics) to outputs (collective decisions) via team member activities (board processes) directed at board tasks (mediators).

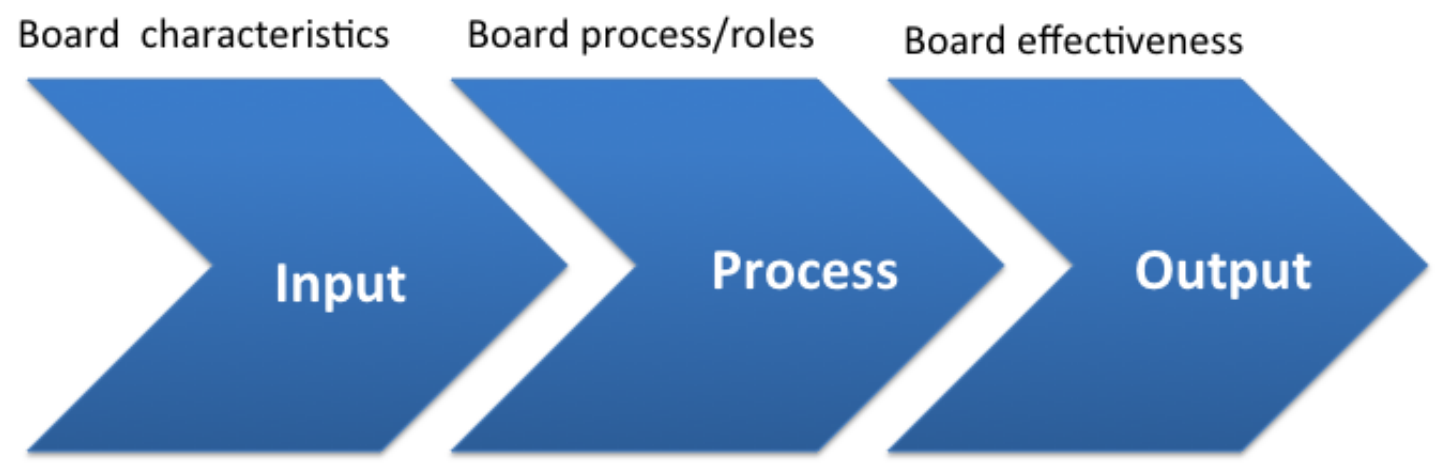

Source: The author

Figure 2. Input-Process-Output (IPO) Model of Board Effectiveness 


\section{Mll Macrothink}

Journal of Corporate Governance Research ISSN 1948-4658 2019, Vol. 3, No. 1

This research largely follows Forbes and Milliken (1999), who observed that boards are basically teams who meet occasionally and have a cognitive output. The authors highlight the importance of researching intervening processes that affect team and eventually company performance. They identify three main board process variables or constructs, namely effort norms, cognitive conflicts and the use of knowledge and skills. These three process constructs are also used and validated by Farquhar (2011) and Minichilli et al. (2012) in their empirical studies on board processes and board effectiveness. Forbes \& Milliken's (1999) model is further expanded by Farquhar (2011), who identified and validated four additional board governance processes drawing on an extensive review of small group literature, namely cohesiveness, communication quality, affective conflict and trust.

Effort norms are a group-level construct that refers to the group's shared beliefs regarding the level of effort each individual is expected to put towards a task" (Forbes \& Milliken, 1999; p. 493). They argue that board members, by doing their "homework", better understand company specifics and strategic issues and that group effort increases individual group members' efforts, and therefore improves the performance of the whole group. Consistent evidence suggests boards with standards promoting high-effort behaviors are more likely to enhance board effectiveness mediated by the board roles (Huse, 2007; Zona and Zattoni, 2007).

Notably Farquhar (2011) and Minichilli et al. (2012) found empirical evidence that board effort norms are positively related to board effectiveness and the relationship between board effort norms and board effectiveness is mediated by board tasks.

According to Jehn (1995, p. 258), cognitive conflicts are task-oriented differences in reasoning between group members, often exhibited in "disagreements about the content of the tasks being performed, including differences in viewpoints, ideas and opinions." (Jehn, 1995, p. 258). An important string of (empirical) studies suggests that cognitive conflict allows groups to make better decisions when conflicting views are presented resulting in better outcomes and reduced group think (Finkelstein \& Mooney, 2003; Huse, 2007; Farquhar, 2011). However, other studies found no significant effect of cognitive conflict on board effectiveness. Zona and Zattoni (2007) suggest that cognitive conflict might trigger the rise of negative emotions within the board, offsetting its positive effects. Minichilli et al (2012) also found no direct meaningful relationship between cognitive conflict and board effectiveness, pointing at a common unwillingness of boards to engage in frank and open discussion.

Heemskerk, Heemskerk and Wats (2015), in their participant observation study of 11 Dutch supervisory boards, found that although high cognitive (task) conflict can be positive for board effectiveness, it can also bring about affective (relationship) conflict, which can decrease board effectiveness. This interaction may explain part of the empirical and theoretical confusion. Therefore, it is not probable that the relationship between cognitive conflict and board effectiveness is a linear one. It is more likely to be curvilinear, a type of relationship between two variables in which when one variable increases the other variable increases too, but only up to a certain point, after which, as one variable continues to increase, 
the other decreases.

Forbes \& Milliken (1999) argue that boards must combine and apply their knowledge and skills in order to perform their tasks effectively. This construct was developed by Hackman \& Morris (1975) and relates to "collective learning" among group members. In the context of board processes, the use of knowledge and skills refers to the board's ability to utilize its knowledge and skills and apply such knowledge and skills to required board tasks (Forbes \& Milliken, 1999).

As such it would be expected that boards of directors that make better use of their knowledge and skills would perform their board roles to a higher standard. This is supported by more recent studies that show that board effectiveness increases when boards make greater use of their knowledge and skills (Wang \& Ong, 2005; Zona \& Zattoni, 2007; Farquhar, 2011; Minichilli et al., 2012).

Forbes \& Milliken (1999, p. 496) define board cohesiveness as "the degree to which board members are attracted to one another and are motivated to stay on the board". Although methodological issues with empirical research on the correlation between cohesiveness and performance have led to incongruent results, most authors now accept the possibility of a cohesiveness-performance relationship (Farquhar, 2011). Notably Beal, Cohen, Burke and McLendon (2003), in their meta-analysis study of cohesiveness and group performance, found strong evidence that all three elements of cohesiveness have a relationship with group performance, especially if the latter is defined as behavior instead of an outcome. This implies that board members with a certain amount of mutual attraction are more stimulated to work together and therefore guarantee their actions are coordinated in such a way they can achieve higher performance levels. In other words, group performance increases when the group is more cohesive.

However, it is unlikely that the relationship between board cohesiveness and board role performance is a linear one. Very high levels of cohesiveness are likely to prove detrimental to the quality of board decision-making, as they may lead to groupthink, a flawed form of group decision-making, defined by a lack of independent and critical thinking, which can result in decisions being accepted uncontested (Forbes \& Milliken, 1999). Therefore, the relationship between cohesiveness and board role performance is more likely to be curvilinear.

Empirical evidence views communication quality as an indicator of positive outcomes (e.g. Massey \& Dawes, 2007; Farquhar, 2011). Quality of communication is defined as the credibility, ease of understanding, relevance, and usefulness of the information provided for the board (Massey \& Dawes, 2007). Communication in organizations can diminish uncertainty, coordinate activities and analyze information. As these activities are crucial for decision-making, communication can affect the operational effectiveness of boards. Huse (2007) also stresses the significance of quality of communication and information for boards to effectively perform their roles.

Affective conflict happens due to relationship or behavioral conflict, negatively affecting the 
group's information processing and decision-making effectiveness. Empirical evidence largely supports the notion that affective conflict has a negative effect on performance outcomes (De Dreu \& Weingart, 2003; Finkelstein \& Mooney, 2003; Wang \& Ong, 2005; Farquhar, 2011).

On the other hand, Heemskerk et al (2015) found that trying to keep levels of conflict low often curbs board effectiveness. They concluded that, while affective conflict is generally considered to have a negative impact on board effectiveness, the prevention of these conflicts is even more damaging. When referring to the interdependency between cognitive (task) and affective (relational) conflict, the authors are mainly pointing to a one-directional reliance from cognitive to affective conflict. However, this can also work the other way around: a certain level of affective conflict can stimulate cognitive conflict and frank discussion and ultimately benefit board effectiveness, but in case of high levels of affective conflict board effectiveness will be negatively affected. This implies that affective conflict within the board may have a curvilinear relationship with board effectiveness.

So far, very few studies have been conducted which research trust on boards. Gillespie \& Mann (2004) found that developing trust is key to developing and sustaining team effectiveness. They identified three kinds of trust - cognitive, affective, and behavioral trust. They also found that trust in leaders is built through team dialogue, open communication and a shared vision. In a study on board effectiveness in the Netherlands, Van Ees, Van der Laan and Postma (2008) found that trust negatively mediates the relationship between the use of knowledge and the control role but showed no other compelling findings. Higher levels of trust could indicate the board is less likely to perform its control role, while it is more likely to increase the board's performance of its service role. On the other hand, Farquhar (2011) found empirical evidence that trust is positively related to board effectiveness via both the control and service roles of the board. Other studies have found that especially the impact of trust on on-going (long-term) teams - such as boards - has a positive effect on task performance, team member satisfaction and team performance (e.g. De Jong \& Elfring, 2010), implying a direct relationship between trust and board effectiveness.

\subsection{Board Roles}

Unless it is clearly established what boards actually do (what tasks they perform or roles they play), or at least what they think their functional objectives should be, it will be difficult to evaluate their effectiveness.

Although the set of board tasks has been subject to considerable debate and ambiguous results (mainly due to ambiguity in terminology), the classification into three broadly defined groups or roles (the control, strategic and service role) was generally accepted in the first wave of literature studies on board roles (e.g. Zahra and Pearce, 1989; Nicholson and Kiel, 2004).

However, empirical testing of especially the strategy and service roles proved questionable (e.g. Wang \& Ong, 2005; Van den Heuvel, Van Gils \& Voordeckers, 2006; Zona \& Zattoni, 2007). More recent empirical evidence indicates there are basically 2 principal board roles, 


\section{Macrothink}

Journal of Corporate Governance Research

ISSN 1948-4658

2019, Vol. 3, No. 1

the control role and the service role (Farquhar, 2011; Minichilli et al, 2012). Especially Farquhar (2011) in his study of UK listed companies, using factor analysis to detect the underlying relationships between board roles, showed that the strategy role was limited to the board's involvement in making decisions on the company's strategy and goals and co-located with the service role. This limitation of the board's strategy role might reflect the difference between what boards actually do and what they are supposed to do according to dominant theories on board roles.

The break-down of these two broad board roles into more specific tasks is shown in the figure below.

ROLE/TASK

\begin{tabular}{|c|c|c|}
\hline & Control & Service \\
\hline External & $\begin{array}{l}\text { Accountability } \\
\text { - Ensuring external } \\
\text { accountabilities are } \\
\text { met, e.g. to stakeholders, } \\
\text { funders, regulators. } \\
\text { - Meeting audit, inspection and } \\
\text { reporting requirements }\end{array}$ & $\begin{array}{l}\text { Networking } \\
\text { - Engaging with external } \\
\text { stakeholders } \\
\text { - Enhancing the organisation's } \\
\text { reputation }\end{array}$ \\
\hline Internal & $\begin{array}{l}\text { Supervision } \\
\text { - Appointing/rewarding/evaluating } \\
\text { senior management } \\
\text { - Monitoring management } \\
\text { decisions } \\
\text { - Monitoring KPI's/ financials/risks } \\
\text { - Board evaluation }\end{array}$ & $\begin{array}{l}\text { Advice and counsel } \\
\text { - Mentor for the CEO and the firm } \\
\text { - Advising the organisation on legal, } \\
\text { accounting, financial, technical, and } \\
\text { marketing issues } \\
\text { - Contributing to long-term strategy } \\
\text { and goals }\end{array}$ \\
\hline
\end{tabular}

Source: Adapted from Garrat (1996), Farquhart (2011)

Figure 3. Board Roles

These two broad roles will be used as mediator variables between board processes (independent or causal variables) and board effectiveness (dependent variable or outcome). This approach follows Farquhar (2011), who found that board role performance mediates the relationship between board processes (independent variables) and board effectiveness (dependent variable). This differs from other studies, who advocate that board processes influence board role performance and use the performance of board roles as proxies for board effectiveness (Van den Heuvel et al., 2006; Zona \& Zattoni, 2007; Minichilli et al., 2012).

A mediator variable (also called intervening or process variable) intervenes in the relationship between the dependent variable (board effectiveness) and the independent variables (in this case the board processes). In this model, the independent variables (board processes) first influence the mediator variables (board roles), and then the mediator variables influence the dependent variable board effectiveness (Baron and Kenny, 1986; Kenny, 2014; Namazi and 
Namazi, 2016). This way board roles (mediator variables) can help to explain the relationship between board processes (independent variables) and board effectiveness (dependent variable). Mediation can be formally assessed using a Sobel test. This test provides a method to establish whether the mediation effect is statistically significant, by assessing whether the devaluation in the impact of the independent variable, after including the mediator in the model, is a significant devaluation (Baron and Kenny, 1986).

\subsection{National Context: The Macro-Level Determinants of Board Effectiveness}

Recent empirical research shows the moderating effect of different legal frameworks, ownerships structures and work-related individual values and behaviours (macro-level determinants) on the relationship between board characteristics, board processes and board effectiveness at the micro-level (e.g. Lubatkin, 2007; Aguilera et al., 2008; Minichilli et al., 2012).

The national context of laws, regulations, voluntary codes and stock exchange listing requirements together form the foundation for corporate governance (Clarke, 2007). These institutional elements are in turn based on the history, culture and political-economic conditions of specific nations (Frentrop, 2003). In this section the different legal-institutional, financial-economic and cultural variables are discussed, including ways to quantify them and make them comparable across national boundaries.

\subsubsection{The Legal Framework}

The legal framework in each country determines how corporate governance is organised (Solomon, 2013). Shleifer and Vishny (1997) were among the first to research the effect of the existing legal framework on a country's corporate governance system, in particular shareholder protection and ownership structure. They found that reduced shareholder protection went hand in hand with weak capital markets.

This emerging picture was confirmed by a group of authors, La Porta, Lopez-de-Silanes, Shleifer and Vishny (1997, 1998, 1999), who published a series of authoritative papers on international corporate governance systems and their underlying determinants. They researched the relationship between legal systems and corporate governance in 49 countries across the globe and found that there are basically three legal traditions.

According to those authors, the French origin legal system offers the weakest shareholder protection. The second, the English origin legal system of common law offers the highest shareholder protection. The third legal tradition, the German and Scandinavian origin legal systems, are somewhere in between these opposite poles.

Common law systems such as the UK's are based on decisions in cases by judges. Corporate governance systems in these countries are more likely to be based on 'voluntary' codes, leaving it up to companies to adhere to them or not. Countries with civil law systems (also known as European Continental Law) such as France only consider legislative ratifications or codification (rather than legal precedents, as in common law) legally binding. Corporate governance reform in these countries is usually achieved through legislative changes to a 
country's corporate or commercial laws (Solomon, 2013).

However, in many countries (common and civil law) voluntary codes have become subject to capital market mechanisms and are sometimes even preconditions for stock market listing. As a result, listed companies will usually fulfil the voluntary parts of a code, or they'll face share price discounts. Moreover, if they want to be listed at certain stock exchanges, they are obliged to adopt these codes, making them quasi-mandatory (Braendle \& Noll, 2006).

According to Aglietta and Reberioux (2005), there are basically three relevant legal fields as far as corporate governance is concerned. The first field is financial market regulation, which tries to improve financial transparency and information disclosure and to prevent insider trading and internal transactions. The second field concerns labour law, which influences corporate governance when it enacts laws regarding worker involvement (codetermination) in corporate decision-making. The third field, corporate law, constitutes the legal framework outlining the relationships between the various elements of the company, including shareholders, company directors, executive management and employees. It deals with such issues as the legal company objectives, shareholding and voting rights, the competence of the general meeting of shareholders, the composition and functioning of the board and the accountability of executive managers and board directors.

In conclusion, it is suggested to analyse the relevant company laws, associated regulations and corporate governance codes in the selected countries in order to establish how corporate governance is organised. Are the legal requirements for corporate governance largely in place? Is there a corporate governance code, and if so is it rule-based (mandatory) or is it voluntary ('comply or explain')? Is the focus of the code more on board structure and procedures or on board values and behaviour? The national company laws generally regulate the operation of the company towards shareholders and their relations with each other. Does director responsibility extend to just shareholders or to all stakeholders, do they have a duty to pursue the long-term well-being of the company? And finally, what governance issues remain unsolved?

\subsubsection{Quality of Public Institutions}

Once the legal and administrative framework in a country has been established, the quality of the institutions that have to upheld and implement these laws and regulations needs to be analyzed. The role of institutions goes further than the legal framework. The approach of government institutions with respect to market freedom and efficiency are also critical: overregulation and red tape, lack of transparency, corruption, lack of quality services supporting the business sector, and political dependence of the judicial system all reduce corporate governance standards and ultimately limit competitiveness and firm performance. Quantitative data from the Global Competitiveness Report (World Economic Forum, 2017) are useful when comparing the quality of public institutions between countries. Especially property rights (including intellectual property protection), ethics and corruption, undue influence (including judicial independence) and public sector performance are relevant for corporate governance and board effectiveness. 


\subsubsection{Ownership Structure}

Ownership structure can also have a substantial effect on a company's corporate governance system (e.g. Shleifer and Vishny, 1997). Two elements of ownership structure are especially relevant in publicly listed companies: owner identity and ownership concentration (Thomson and Conyon, 2012). Owner identity has implications for their objectives and the way they exercise their power. This is demonstrated in the owners' strategy with regard to profit targets, dividend policy, capital structure and growth levels. Ownership concentration measures the power of shareholders to influence managers. Up to a certain point, all shareholders benefit from greater ownership concentration because a large owner has the power and incentives to maximize company performance or to see to it that management maximizes performance. The sheer size of large institutional investors and their knowledge of the stock market allows them to compare companies and if needed punish unwanted behavior by eliminating them from their portfolio.

This diversity between shareholders also underlines a coordination problem, which can result in a lack of effective control of the firm. Working out this 'free rider' problem is an important objective of effective corporate governance settlement.

\subsubsection{Financial Market Development}

It is only recently that financial market development is also taken into consideration (Aguilera et al., 2008; Minichilli et al., 2012). The last financial crisis has underlined the importance of a healthy and well-functioning financial sector. Healthy financial markets can provide capital for private sector investment via bank loans, well-regulated stock markets, venture capital and other financial instruments. Financial institutions act in a way as overseers of corporate success and play as such a key role in corporate governance systems. Consequently, banks and stock markets present a crucial part of institutional arrangements for corporate governance. They require suitable regulation to protect the rights of investors and other economic players. This presupposes vigorous bank balance sheets, healthy competition and effective financial control (World Economic Forum, 2017).

A country's financial system's assets as a proportion of GDP are a first indicator of the relevance of financial markets for the private investment sector. A large financial system generally implies that financial regulations are in place to protect investors. The Global Competitiveness Report (World Economic Forum, 2017) ranks countries in terms of financial market development. The dimension efficiency of the financial markets is composed of variables such as availability and affordability of financial services and access to and availability of equity financing, loans and venture capital. This shows whether a country has a competitive and efficient financial mechanism. Another relevant composite dimension is 'trustworthiness and confidence', which shows whether the financial system (including stock markets) in a country is overall trustworthy and offers sound legal protection.

As this study focuses on listed companies, the stock market is of particular interest. Again, the market capitalization of the national stock exchange is a first indication.

The Global Competitiveness Report 2017 (World Economic Forum, 2017) provides 
comparable dimensions regarding the competitiveness, efficiency and the stability of the regulatory environment of the national stock markets.

\subsubsection{National Culture and Work-Related Values}

Apart from the abovementioned legal-institutional and financial-economic factors, board effectiveness can also be affected by cultural values representing different national contexts. There are many definitions of national culture. Most of them refer to a 'shared meaning system' or 'complex of meanings, symbols and assumptions about what is good or bad' (Triandis, 2000; Licht, Goldsmidt, \& Schwartz, 2005). Hofstede (1980, p. 25) defines culture as "the collective programming of the mind distinguishing the members of one group or category of people from others". As such, national culture also influences work-related values and behaviors, and subsequently board characteristics and processes. According to Geletkanycz (1996, p. 617), managers "experience social reinforcement pressures which bring their individual-level assumptions and preferences into close alignment with those of their native culture".

Several studies on cross-cultural values show significant differences between work-related individual values and behaviors due to the wider political, psychological and sociological effect of nationality (e.g. Hofstede, 1980, 1983, 1991, 2001; Hofstede, Van Deusen, Mueller and Charles, 2002; Gomez-Mejia \& Wiseman, 2007; Kirkman, Chen, Farh, Chen, \& Lowe, 2009; Minichilli et al., 2012). These differences not only influence certain board characteristics via habits and rules embedded in institutional environments (McNulty \& Pettigrew, 1996), but can potentially also affect board processes (Hambrick, Werder and Zajac, 2008; Minichilli et al, 2012) and ultimately board effectiveness. Minichilli et al (2012), in their comparative study of macro and micro determinants of board effectiveness in Norway and Italy, have found empirical evidence that not only legal-institutional and financial-economic factors, but also different cultural factors have a moderating effect on the relationship between board processes and board task performance at the micro-level.

The best-known and most applied theoretical and empirical work on value development within national cultures has been developed by Geert Hofstede (1980). Hofstede organized one of the most inclusive studies of how culture influences values in the workplace. In his model of national culture, Hofstede originally distinguished four dimensions: Individualism/collectivism, power distance, uncertainty avoidance and masculinity/femininity. The model was later enlarged with a fifth dimension, long-term versus short-term orientation (Bond, 1987). Finally, Minkov (2007) added a sixth dimension, indulgence versus restraint. These dimensions depict broad tendencies (or values) "to prefer certain states of affairs over others" that differentiate countries (rather than individuals) from one another (Hofstede, 1980, p. 19).

Taras, Kirkman and Steel (2010) in their meta-analysis of 598 studies concluded that the four original cultural values of Hofstede's model are equally important in terms of anticipating outcomes. Secondly, they found that the prognostic potential of cultural values is much lower than that of demographics and personality traits for certain results like job performance, but considerably higher for e.g. team-related attitudes, identification, organizational commitment 
and feedback seeking. Lastly, cultural values are more heavily connected to results for managers, older, male, and more educated respondents. This implies that cultural values might have a significant moderating effect on board processes and ultimately board effectiveness, a conclusion which has been empirically supported by Minichilli et al. (2012).

Culture is a relative term and can only be used meaningfully when comparing different countries. In order to assure sufficient between-country variation (Tsui, Nifadkar and Ou, 2007) and be able to draw relevant conclusions about their possible moderating effect on board characteristics and processes and ultimately board effectiveness, it would be advised to focus on the most opposite work-related cultural values.

The first cultural value dimension, individualism-collectivism, is defined as "the degree to which people in a country prefer to act as individuals rather than as members of groups" (Hofstede, 1994, p. 6). More specifically, individualism is "a loosely knit social framework in which people are supposed to take care of themselves and of their immediate families only" (Hofstede, 1980, p. 45).

Countries that score high on individualism might experience overconfidence in the capability of managers to manage the company, and, accordingly, emphasize individual decision-making over group consensus (Geletkanycz, 1997). This might limit cognitive conflict, stifle open and constructive debate and refrain the board from considering a broader range of alternatives. Individualism might also reduce group cohesiveness, the degree in which board members like each other and like the group they are part of.

Collectivist societies on the other hand are generally more focused on relationships than tasks (Sosik \& Jung, 2002). This becomes evident in an intimate and long-ranging commitment to the member group. Loyalty is preeminent, and supersedes most other social principles and members take responsibility for others in the same group. Strong collectivist tendencies may stifle open and constructive debate in the board, as conflicts will be avoided. This can lead to boards 'rubber stamping' decisions without much debate, reducing the quality of decision-making and ultimately board effectiveness. Wageman (1995) also found that the actual active use of knowledge and skills has a reduced effect on board performance in collectivistic societies compared to individualistic societies.

Power distance is the second most researched cultural value (Erez, 2011). Power distance refers to "the extent to which a society accepts the fact that power in institutions and organizations is distributed unequally" (Hofstede, 1980, p. 45). This dimension copes with inequality in societies - it articulates the attitude of society with regard to these inequalities. Rather, it is the degree to which reports are not supposed to articulate discord with their superiors and superiors are not supposed to consult their reports in the decision-making process (Hofstede, 1980, 2001).

In countries characterized by low levels of power distance, individual subordinates usually tend to participate in decision-making (Hofstede, 1984). As such, active participation tends to succeed over hierarchy in decision-making (Geletkanycz, 1997). Also, cognitive conflicts are probably more encouraged than curbed. They may further reduce hierarchical and cognitive 
obstacles among board members (for instance between insiders and outsiders) and create an environment in which they can enter in open and fruitful debate. Finally, it is likely that collective learning among team members is stimulated in these conditions, increasing the use of knowledge and skills within the board.

High power distance contexts on the other hand may limit open debate, as hierarchy trumps active participation (Geletkanycz, 1997). In a high power culture it is more probable that cognitive conflicts are curbed, as they would reduce hierarchical hurdles among members of the board.

The third dimension, uncertainty avoidance is defined as "the extent to which a society feels threatened by uncertain and ambiguous situations and tries to avoid these situations by providing greater career stability, establishing more formal rules, not tolerating deviant ideas and behaviors, and believing in absolute truths and the attainment of expertise" (Hofstede, 1980, p. 45).

However, uncertainty avoidance is not the same as risk avoidance - "it does not describe one's willingness to take or avoid risk, but rather is associated with preferences for clear rules and guidance" (Hofstede, 2001, p. 149). It deals with the degree to which people are scared by inconclusive or unfamiliar situations and have developed notions and institutions that try to avoid these.

In low uncertainty avoidance contexts, boards are more likely to be relatively comfortable in ambiguous situations, especially when there is a fair amount of trust in the chair and/or CEO and the quality of communication is high. Cognitive conflicts and differing opinions are more readily accepted, spurring open debate, which is only checked by a certain level of shared values, beliefs and (effort) norms. Performance rather than conformance tends to be the rule (Hofstede, 1980).

Countries who score high on this dimension usually almost have an emotional necessity for clear rules and regulations and innovation is more likely to be opposed (Hofstede-insights, n.d.). Boards are more likely to be relatively uncomfortable in ambiguous situations. Cognitive conflicts and differing opinions are not easily accepted, which is stifling open debate. Conformance rather than performance tends to be the rule (Hofstede, 1980).

Lastly, a high masculinity context indicates that society is driven by ambition, competition and distinct gender roles. This dimension focusses on the extent to which a society stresses achievement or nurture (Hofstede, 2001). Board processes tend to be more confrontational and high on effort norms, with some board members being more equal than others based on their status. The role of the chair is important in assuring that the knowledge and expertise of all board members is used and the cohesiveness of the board is preserved.

In countries with a more feminine score, the dominant values are caring for others and quality of life (Hofstede, 2001). In low masculinity contexts, boards are more likely to be focused on relationships rather than tasks (high cohesiveness), conflicts will be avoided and all board members will be able to contribute to the discussions. On the downside, this focus on relationships may also stifle open debate and sensitive decisions may be delayed. 


\section{Macrothink}

Journal of Corporate Governance Research

ISSN 1948-4658

2019, Vol. 3, No. 1

In line with Wan \& Hoskisson (2003) and Minichilli et al (2012), two composite measures are composed to provide evidence of the differences between countries. Unlike the previous authors, this study uses one legal- institutional and one financial-economic composite, the latter stressing the importance of financial market development for corporate governance practice. A third measure - culture - has not been composed, as scores on cultural dimensions (Hofstede's work-related values) cannot be added up. Instead, the individual dimensions are shown and can be used to explain certain outcomes on board characteristics, board processes and board effectiveness.

\begin{tabular}{|c|c|c|}
\hline & Country A & Country B \\
\hline Legal-institutional (mean) & $\mu$ & $\mu$ \\
\hline - Property rights & $1-10$ & $1-10$ \\
\hline Ethics \& corruption & $1-10$ & $1-10$ \\
\hline Undue influence & $1-10$ & $1-10$ \\
\hline $\begin{array}{ll}\text { Public sector } \\
\text { performance }\end{array}$ & $1-10$ & $1-10$ \\
\hline Financial-economic (mean) & $\mu$ & $\mu$ \\
\hline - Efficiency & $1-10$ & 4 \\
\hline $\begin{array}{l}\text { - } \quad \text { Regulation of security } \\
\text { exchanges }\end{array}$ & $1-10$ & 4,9 \\
\hline \multicolumn{3}{|l|}{ Cultural (high/low) } \\
\hline - Individualism & $1-10$ & $1-10$ \\
\hline Power distance & $1-10$ & $1-10$ \\
\hline Uncertainty avoidance & $1-10$ & $1-10$ \\
\hline Masculinity & $1-10$ & $1-10$ \\
\hline
\end{tabular}

Source: The author (2018)

Figure 4. Legal-institutional, Financial-economic and Cultural Variables

The suggested research method concerns multi-source secondary data, specifically compiled databases, such as national cultural scores (Hofstede-insights, n.d.) and legal-institutional and financial-economic indicators in the countries under study (World Economic Forum, 2017).

Consequently, this research adopts a macro-level (national context) approach to board effectiveness, in which the effect of these macro-level determinants on micro-level board characteristics and processes, and ultimately board effectiveness is analysed. This perspective is visually represented in Figure 5 below. 


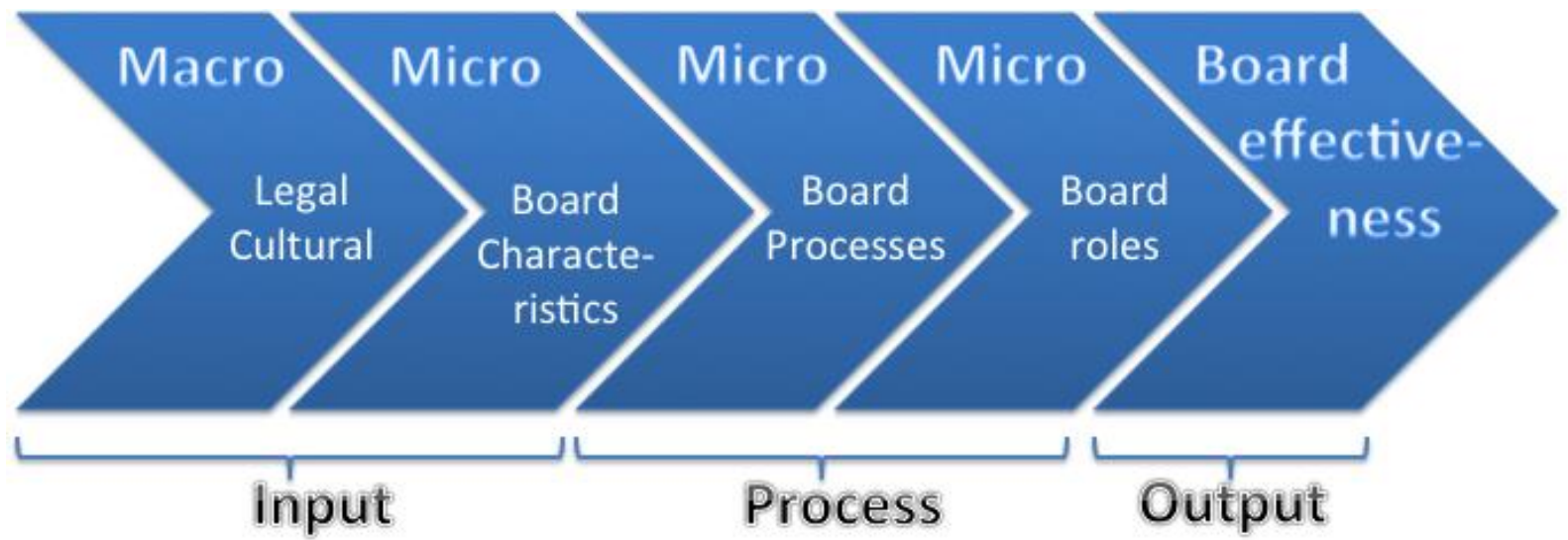

Source: The author (2018)

Figure 5. Macro- and Micro-Determinants of Board Effectiveness

\subsection{Board Effectiveness Model and Measurement}

Based on the previous considerations, the following theoretical framework for evaluating board effectiveness has been developed (Figure 6). It will be used to design an appropriate research strategy for cross-national board effectiveness research.

\begin{tabular}{|c|c|c|c|}
\hline $\begin{array}{c}\text { Independent } \\
\text { variables }\end{array}$ & $\begin{array}{c}\text { Control } \\
\text { variables }\end{array}$ & $\begin{array}{c}\text { Independent } \\
\text { variables }\end{array}$ & $\begin{array}{c}\text { Mediating } \\
\text { variables }\end{array}$ \\
\hline
\end{tabular}
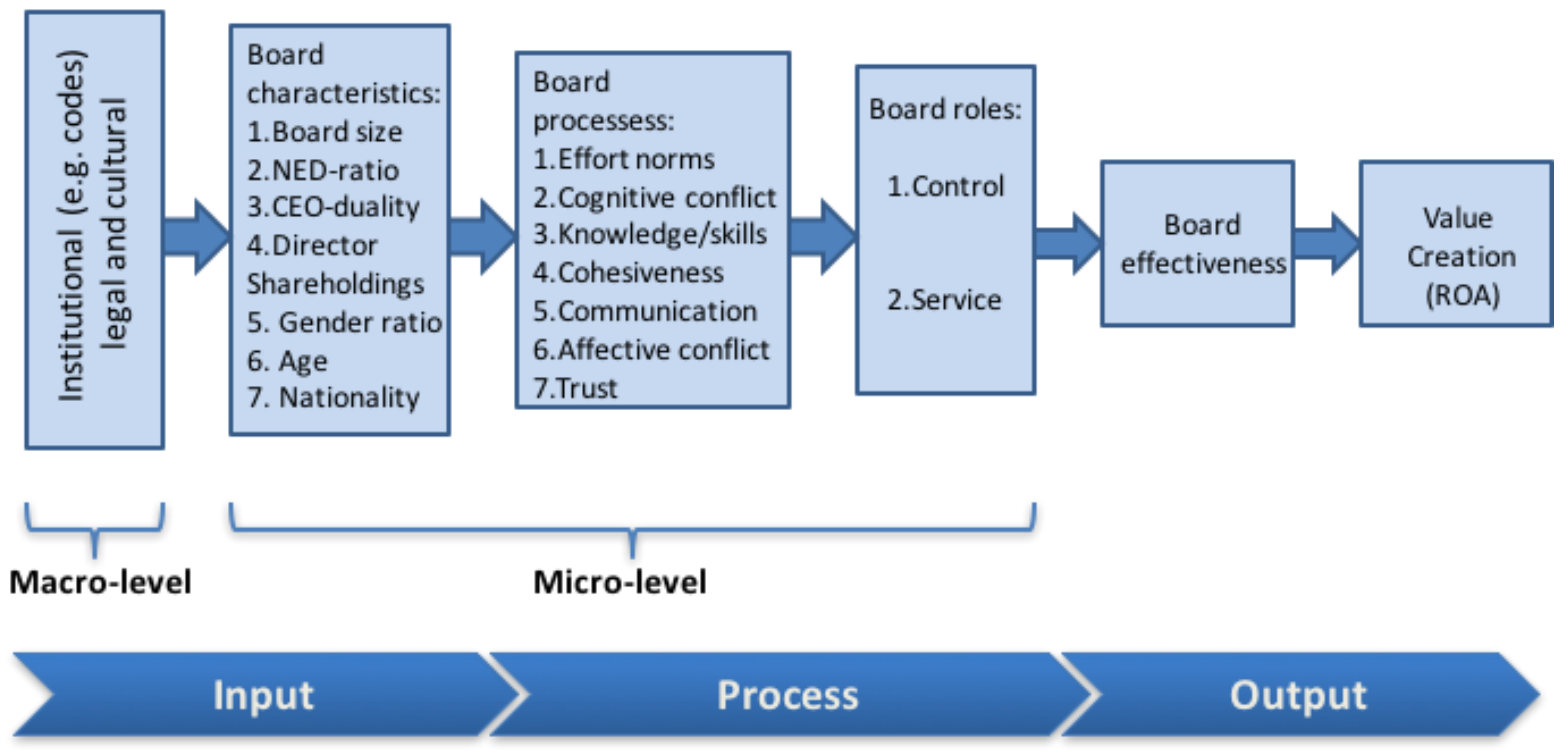

Source: Derived from Farquhar (2011) and Minichilli et al. (2012)

Figure 6. Theoretical Construct for Analysing Board Effectiveness 
As stated before, most corporate governance research uses the concept of 'board task performance' as a proxy for board effectiveness (e.g. Forbes \& Milliken, 1999; Huse, 2005; Minichilli et al., 2009; Minichilli et al., 2012). In this concept, board effectiveness is measured based on how satisfied the board is (self-evaluation) with the way they undertake their board roles, assuming there is a direct relationship between board role performance and board effectiveness.

Instead, this research proposes to measure board effectiveness directly through a validated four-item construct based on previous literature (e.g. Aguilera, 2005; Huse, 2005; Farquhar, 2011). These validated items are:

- Our board adds value to the company.

- Our board improves company performance in the interest of shareholders and other stakeholders.

- Board members are satisfied with the board performance.

- Our board is satisfied with board members' role performance.

This study proposes a survey method with responses from chairs on behalf of the whole board. Board effectiveness studies are mainly based on a sole respondent, usually the CEO, who is generally considered being best positioned in terms of knowledge of the company and the board (e.g. Daily et al., 2003). However, as the focus of this study is on board processes, it is the chairman who is ultimately responsible for directing these processes and as such the most relevant person to question. Some authors also consider chairs to be more independent and less biased than CEO's (e.g. Farquhar, 2011).

The survey should contain closed-ended questions about board effectiveness, board processes and board roles, allowing for quantitative analysis using statistical procedures. Most questions are based on multiple-item constructs measured through a seven-point Liker-type scale, with items ranging from 4 statements to 10 statements for each construct. In social science many attitude scales like Liker - where respondents have to state whether they agree or disagree with a certain statement - are considered to be interval scales. In interval scales, numbers are used to rank items in a numerically equal distance, representing equal distance in the item being measured. This is in line with other empirical board studies, where Liker scales are usually considered as interval scales (e.g. Minichilli et al., 2009; Farquhar, 2011; Minichilli et al, 2012). Generally, rating scales with a larger number of points will produce higher sensitivity of measurement and distillation of variance (Blumberg, Cooper, \& Schindler, 2008).

Next, a regression analysis following three steps is suggested. First, the independent variable (board process) is regressed (A) against the mediating variables (control and service role). Second, the independent variable (board process) is regressed (C) against the dependent variable (board effectiveness). In order to check whether the relationship between the independent variable (board process) and the dependent variable (board effectiveness) is a non-linear one, independent variable squared was regressed against the dependent variable. Thirdly, the mediating variables (control and service roles) are regressed (B) against the 


\section{Macrothink}

Journal of Corporate Governance Research

ISSN 1948-4658

2019, Vol. 3, No. 1

dependent variable (board effectiveness). This statistical process is graphically represented in Figure 7:
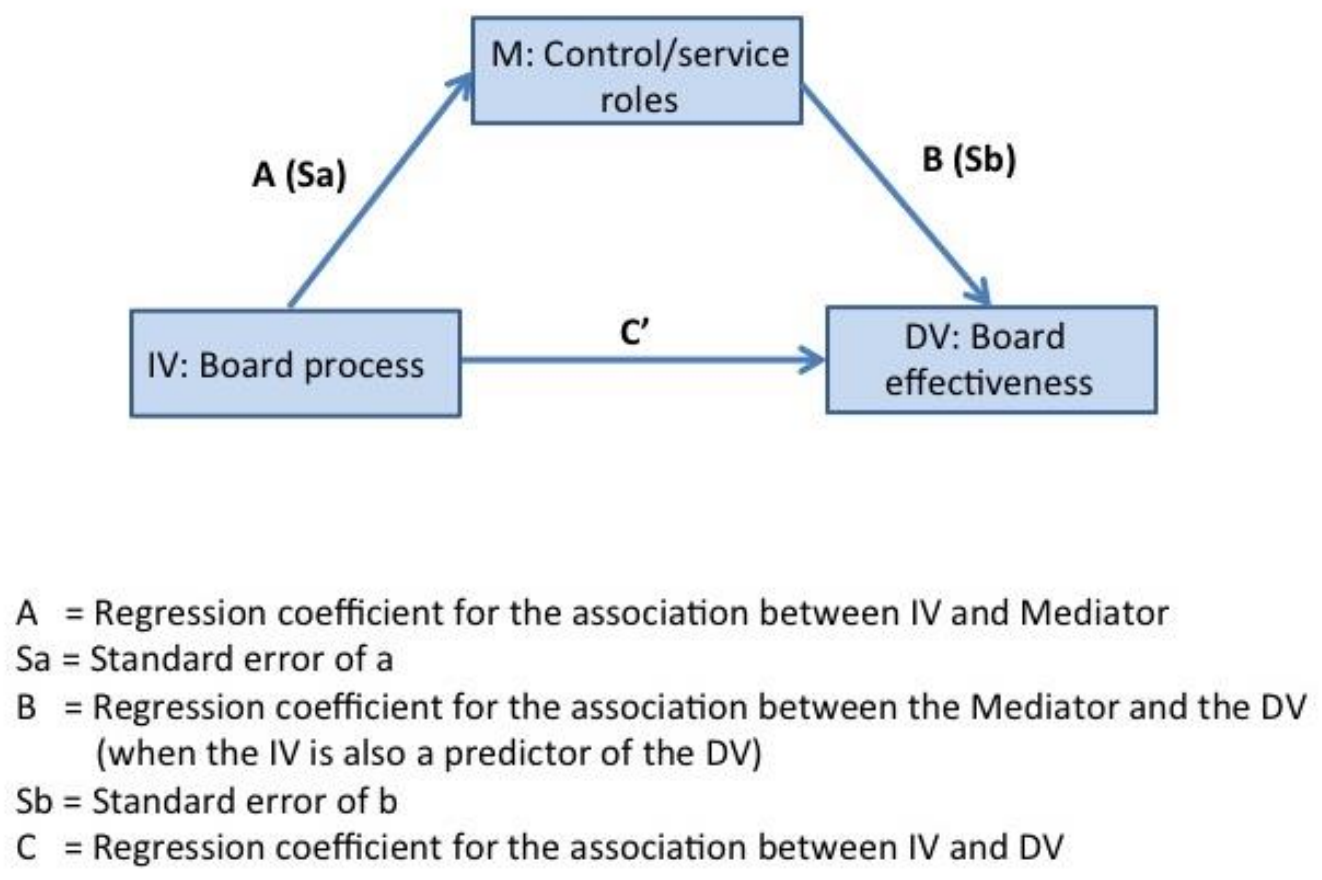

Source: Preacher, K. (2017), Calculation for the Sobel test: An interactive calculation tool for mediation tests.

Retrieved from: http://quantpsy.org/sobel/sobel.htm

Figure 7. Regression Analysis and Mediation Assessment Process

The regression analysis is done for 2 different models, one without control variables and one with control variables (the 7 selected board characteristics).

Additionally, a Sobel test is proposed using $\mathrm{A} / \mathrm{Sa}$ and $\mathrm{B} / \mathrm{Sb}$ as input to determine the significance of the mediating variables for the independent variables. The Aroian version of the Sobel test is applied, as suggested by Baron and Kenny (1986), which is represented by the following formula: $z$-value $=a^{*} b / \operatorname{SQRT}\left(b^{2 *} s_{a}{ }^{2}+a^{2 *} s_{b}{ }^{2}+s_{a}{ }^{2 *} s_{b}{ }^{2}\right)$.

Finally, this board effectiveness construct is further validated by connecting it to firm performance. Farquhar (2011) found a convincing positive relationship between Return on Capital Employed (ROCE) and board effectiveness, concluding that the construct is a valid measure for the added value of boards. In case the research sample is more skewed towards manufacturing firms, it is suggested to use Return on Assets (ROA) instead of ROCE (Henderson, Miller, \& Hambrick, 2006; Minichilli et al., 2012). The return on assets (ROA) ratio illustrates how well management is employing the company's total assets to make a profit. This way board effectiveness, the dependent variable in the analysis, is more directly linked to the contribution of the board to firm performance in general, instead of just on the evaluation of board roles. 
In conclusion, based on Huse's and Gabrielssons's taxonomy of board research, this board effectiveness model can be categorised as a combination of contingency and behavioural perspectives, where the contingency perspective acknowledges the impact of the legal-institutional and cultural context on board and firm performance, and the behavioural perspective which focuses on decision-making processes and interactions inside and outside the boardroom (Huse, 2009).

\section{Discussion}

There is a general lack of shared frameworks and theoretical concepts in corporate governance and board effectiveness research, which hampers empirical breakthrough and international comparison. This research tries to bridge this gap by developing a multi-disciplinary and multi-theoretical approach to board effectiveness, using mainly quantifiable inputs. The resulting comparative model of board effectiveness which is presented in this study can help to clarify the macro- and micro-level drivers of board effectiveness. It allows for an analogy of board effectiveness between different national contexts and can ultimately lead to practical solutions to improve board effectiveness for both practicing board members and national policy makers.

By focusing on board processes rather than board characteristics, this research tries to increase understanding of the role and workings of boards, which can help board members and especially chairs to improve the effectiveness of their boards. It can also help policy-makers to better understand corporate behavior and set policies to regulate corporate activities accordingly.

Additionally, the cross-national context of this study is relevant against the background of the increasing internationalization of boards. This implies that the understanding of legal-institutional factors, financial-economic indicators and dimensions of national culture (work related values) and its effect on board processes becomes increasingly important for boards and especially chairs to take into consideration.

The previous sections have presented a holistic framework and method for analyzing board effectiveness, including which research methods to use. Empirical application of this framework to listed companies in different national contexts will undoubtedly further enhance our understanding of the inner workings of the board and the factors that influence them.

\section{Acknowledgement}

I would like to express my sincere gratitude to my advisor and mentor, Prof. dr. ir. MAM Boersma, who encouraged me to start a $\mathrm{PhD}$ research on board effectiveness in different national contexts. Without his continuous support and advice, I wouldn't have made the journey till here. 


\section{References}

Abatecola, G., Farina, V., \& Gordini, N. (2014) Board effectiveness in corporate crises: lessons from the evolving empirical research. Corporate Governance, 14(4), 531-542. https://doi.org/10.1108/CG-03-2013-0030

Abdullah, A., \& Page, M. (2009). Corporate governance and corporate performance: UK FTSE 350 companies. The Institute of Chartered Accountants of Scotland.

Aglietta, M., \& Rebérioux, A. (2005). Corporate Governance adrift: A Critique of Shareholder Value. Cheltenham: Edward Elgar. https://doi.org/10.4337/9781845425470

Aguilera, R. V. (2005). Corporate governance and director accountability: An institutional comparative perspective. British Journal of Management, 16, 39-53. https://doi.org/10.1111/j.1467-8551.2005.00446.x

Aguilera, R. V., Filatotchev, I., Gospel, H., \& Jackson, G. (2008). An organizational approach to comparative corporate governance: Costs, contingencies, and $\begin{array}{llll}\text { complementarities. } & \text { Organization } & \text { Science, } & 19,\end{array}$ https://doi.org/10.1287/orsc.1070.0322

Aquilera, R. V., \& Cuervo-Cazurra, A. (2009, May). Codes of good governance. Corporate $\begin{array}{llll}\text { Governance. An } \quad \text { International } & \text { Review, }\end{array}$ https://doi.org/10.1111/j.1467-8683.2009.00737

Baron, R., \& Kenny, D. (1986). The moderator-mediator variable distinction in social psychological research: conceptual, strategic, and statistical considerations. Journal of Personality and Social Psychology, 51(6), 1173-1182. https://doi.org/10.1037/0022-3514.51.6.1173

Beal, D., Cohen, R., Burke, M., \& McLendon, C. (2003). Cohesiveness and performance in groups: a meta-analytic clarification of construct relations. Journal of Applied Psychology, 88(6), 989-1004. https://doi.org/10.1037/0021-9010.88.6.989

Bhagat, S., \& Black, B. (2001). The non-correlation between board independence and long-term firm performance. Journal of Corporation Law, 27, 231-274.

Blair, M. M. (1995). Ownership and Control: Rethinking Corporate Governance for the 21st Century. Washington, DC: Brookings Institute.

Blumberg, B., Cooper, D. R., \& Schindler, P. S. (2008). Business research methods (2nd European Ed.). Maidenhead, Berkshire: McGraw-Hill Education.

Bond, M. (1987). Chinese Culture Connection. Chinese values and the search for culture-free dimensions of culture. Journal of Cross-Cultural Psychology, 18, 143-164. https://doi.org/10.1177/0022002187018002002

Braendle, U. C., \& Noll, J. (2006). Enlarged EU: Enlarged corporate governance? Why directives might be more appropriate for transition economies. Corporate Governance, 6(3), 296-304. https://doi.org/10.1108/14720700610671891 
Clarke, T. (1998). The Stakeholder Corporation: A Business Philosophy for the Information Age. Long Range Planning, 31(2), 182-194. https://doi.org/10.3138/9781442673496-003

Clarke, T. (2007). International corporate governance. A comparative approach. Routledge 2007. https://doi.org/10.4324/9780203300725

Cohen S. G., \& Bailey D. E. (1997). What makes teams work: group effectiveness research from the shop floor to the executive suite. Journal of Management, 23(3), 239-290. https://doi.org/10.1177/014920639702300303

Conger, J. A., \& Lawler, E. (2001, April). 'Building a high-performing board: how to choose the right members'. London Business School Business Strategy Review, 12.

Daily, C. M., \& Johnson, J. (1997). Sources of CEO Power and Firm Financial Performance: A Longitudinal Assessment. Journal of Management 23(2), 97-117. https://doi.org/10.1177/014920639702300201

Daily, C. M., Dalton, D. R., \& Canella, A. A. (2003). Corporate governance: decades of dialogue and data. Academy of Management Review, 28(3), 371-382. https://doi.org/10.5465/amr.2003.10196703

De Dreu, C., \& Weingart, L. R. (2003). Task versus relationship conflict, team performance, and team member satisfaction. Journal of Applied Psychology, 88(4), 741-749. https://doi.org/10.1037/0021-9010.88.4.741

De Jong, B., \& Elfring, T. (2010). How does trust affect the performance of ongoing teams? The mediating role of reflexivity, monitoring, and effort. Academy of Management Journal, 53(3), 535-549. https://doi.org/10.5465/amj.2010.51468649

Erez, M. (2011). Cross-cultural and global issues in organizational psychology. APA handbook of industrial and organizational psychology, vol. 3: 807-854. Washington, DC: American Psychological Association.

Fama, E. F., \& Jensen, M. C., (1983). Separation of ownership and control. Journal of Law and Economics, 26, 301-325. https://doi.org/10.1086/467037

Farquhar, S. (2011). The impact of board processes on board role performance and effectiveness: An empirical study of UK listed companies. A thesis submitted in partial fulfillment of the requirements of the University of Wolverhampton for the degree of DOCTOR OF PHILOSOPHY. November 2011.

Finkelstein, S., \& Mooney, A. C. (2003). Not the usual suspects: how to use the board process to make boards better. Academy of Management Executive, 17(2), 489-505. https://doi.org/10.5465/ame.2003.10025204

Forbes, D. P., \& F. J. Milliken (1999). Cognition and Corporate Governance: Understanding Boards of Directors as Strategic Decision-Making Groups. Academy of Management Review, 24, 489-505. https://doi.org/10.2307/259138 
Frentrop, P. M. L. (2003). A History of Corporate Governance 1602-2002. Brussels: Deminor.

Garratt, B. (1996). The Fish Rots from the Head. HarperCollins Business, London.

Geletkanycz, M. A. (1997). The salience of culture's consequences: The effects of cultural values on top executive commitment to the status quo. Strategic Management Journal, 18 ,

615-634.

https://doi.org/10.1002/(SICI)1097-0266(199709)18:8<615::AID-SMJ889>3.0.CO;2-I

Gillespie, N. A., \& Mann, L. (2004). Transformational leadership and shared values: the building blocks of trust. Journal of Managerial Psychology, 19(6), 588-607. https://doi.org/10.1108/02683940410551507

Hackman J. R., \& Morris C. (1975). Group task group interaction process and group performance effectiveness. A review and proposed integration. L. Berkowitz (ed.). Advances in experimental social psychology, 8, 45-99. https://doi.org/10.1016/S0065-2601(08)60248-8

Hambrick, D. C., Werder, A., \& Zajac, E. J. (2008). New Directions in corporate governance research. Organization Science, 19, 381-385. https://doi.org/10.1287/orsc.1080.0361

Heemskerk, E., Heemskerk, K., \& Wats, M. (2015, December). Conflict in the boardroom: a participant observation study of supervisory board dynamics. Journal of Management and Governance. December 2015.

Henderson, A. D., Miller, D., \& Hambrick, D. C. (2006). How quickly do CEOs become obsolete? Industry dynamism, CEO tenure, and company performance. Strategic Management Journal, 27, 447-460. https://doi.org/10.1002/smj.524

Hermalin, B., \& Weisbach, M. (2003). Boards of directors as an endogenously determined institution: a survey of the economic literature. Economic Policy Review, 9(1), 7-26.

Hofstede, G. (1980). Culture's consequences: International differences in work-related values. Newbury Park, CA: Sage.

Hofstede, G. (1983). The cultural relativity of organizational practices and theories. Journal of International Business Studies, f5-89. https://doi.org/10.1057/palgrave.jibs.8490867

Hofstede, G. (1984). The cultural relativity of the quality of life concept. Academy of Management Review, 93, 389-398. https://doi.org/10.5465/amr.1984.4279653

Hofstede, G. (1991). Cultures and organizations: Software of the mind. London: McGraw-Hill. De Jong.

Hofstede, G. (2001). Culture's consequences: Comparing values, behaviors, institutions and organizations across nations (2nd ed.). Thousand Oaks: Sage.

Hofstede, G., Van Deusen, C. A., Mueller, C. B., \& Charles, T. A. (2002) What goals do 
business leaders pursue? A study in fifteen countries. Journal of International Business Studies, 33, 785-803. https://doi.org/10.1057/palgrave.jibs.8491044

Hofstede-Insights (n.d.). Retrieved

from

https://www.hofstede-insights.com/product/compare-countries/

Huse, M. (2005). Accountability and creating accountability: A framework for exploring behavioral perspectives of corporate governance. British Journal of Management, 16, 65-79. https://doi.org/10.1111/j.1467-8551.2005.00448.x

Huse, M. (2007). Boards, governance and value creation: The human side of corporate governance. Cambridge: Cambridge University Press. https://doi.org/10.1017/CBO9780511611070

Huse, M. (ed., 2009). The value creating board. Corporate governance and organizational behavior. Routledge, 2009.

Jehn, K. (1995). A multimethod examination of the benefits and detriments of intragroup conflicts. Administrative Science Quarterly, 40, 256-282. https://doi.org/10.2307/2393638

Jensen, M. C., \& Meckling, W. H. (1976). Theory of the firm: managerial behavior, agency costs and ownership structure. Journal of Financial Economics, 4, 305-60. https://doi.org/10.1016/0304-405X(76)90026-X

Johnson, J. L., Ellstrand, A. E., Dalton, C. M., \& Dalton, D. R. (2004). A fine-grained analysis of director dependence: examining board composition in detail. Journal of Business Strategies, 21(2), 111-132.

Kenny, D. A. (2014). Mediation. https://doi.org/10.1002/9781118445112.stat06605

Kirkman, B. L., Lowe, K. B., \& Gibson, C. B. (2006). A quarter century of Culture's Consequences: A review of empirical research incorporating Hofstede's cultural values framework. Journal of International Business Studies, 37, 285-320. https://doi.org/10.1057/palgrave.jibs.8400202

Kirkman, B., Chen, G., Farh, J., Chen, Z., \& Lowe, K. (2009, August). Individual Power Distance Orientation and Follower Reactions to Transformational Leaders: A Cross-Level, Cross-Cultural Examination. The Academy of Management Journal, 52(4), 744-764. https://doi.org/10.5465/amj.2009.43669971

La Porta, R., Lopez-de-Silanes, F., \& Shleifer, A. (1999) Corporate ownership around the world. Journal of Finance, 54, 471-517. https://doi.org/10.1111/0022-1082.00115

La Porta, R., Lopez-de-Silanes, F., Shleifer, A., \& Vishny, R. W. (1998). Law and finance. Journal of Political Economy, 106, 1113-55. https://doi.org/10.1086/250042

La Porta, R., Lopez-de-Silanes, F., Shleifer, A., \& Vishny, R. (1997, July). Legal determinants of external finance. The Journal of Finance, LII(3), 1131-1150. https://doi.org/10.1111/j.1540-6261.1997.tb02727.x 


\section{MInstitute ${ }_{\text {Mnk }}^{\text {Macrothin }}$}

Journal of Corporate Governance Research ISSN 1948-4658

Lawal, B, (2012, January). Board Dynamics and Corporate Performance: Review of Literature, and Empirical Challenges. International Journal of Economics and Finance, 4(1). https://doi.org/10.5539/ijef.v4n1p22

Levrau, A., \& Van den Berghe, L. A. A. (2007). Corporate governance and board effectiveness: Beyond Formalism. ICFAI Journal of Corporate Governance, 6(4), 58-85.

Licht, A. N., Goldschmidt, C., \& Schwartz, S. H. (2005). Culture, law, and corporate governance. International Review of Law and Economics, 25, 229-255. https://doi.org/10.1016/j.irle.2005.06.005

Lubatkin, M. (2007). One more time: What is a realistic theory of corporate governance? Journal of Organizational Behavior, 28, 59-67. https://doi.org/10.1002/job.403

Lückerath-Rovers (2013, May). Women on boards and firm performance. Journal of $\begin{array}{llll}\text { Management } \quad \text { Governance, } & \text { 491-509. }\end{array}$ https://doi.org/10.1007/s10997-011-9186-1

Marks, M. A., Mathieu, J. E., \& Zaccaro, S. J. (2001). A temporally based framework and taxonomy of team processes. Academy of Management Review, 26(3), 356-376. https://doi.org/10.2307/259182

Massey, G. R., \& Dawes, P. L. (2007). The antecedents and consequence of functional and dysfunctional conflict between marketing managers and sales managers. Industrial Marketing Management, $\quad 36$

1118-1129. https://doi.org/10.1016/j.indmarman.2006.05.017

McNulty, T., \& Pettigrew, A. (1996). The contribution, power and influence of part-time board members. Corporate Governance: An International Review, 4(3), 60-79. https://doi.org/10.1111/j.1467-8683.1996.tb00145.x

Minichilli, A., Zattoni, A., \& Zona, F. (2009). "Making boards effective: an empirical examination of board task performance". British Journal of Management, 20(1), 55-74. https://doi.org/10.1111/j.1467-8551.2008.00591.x

Minichilli, A., Zattoni, A., Nielsen, S., \& Huse, M. (2012). Board task performance: An exploration of micro-and macro-level determinants of board effectiveness. Journal of Organizational Behavior, 33(2), 193-215. https://doi.org/10.1002/job.743

Minkov, M. (2007). What makes us different and similar: A new interpretation of the World Values Survey and other cross-cultural data. Sofia, Bulgaria: Klasika y Stil Publishing House.

Nicholson G. C., \& Kiel G. C. (2004). A framework for diagnosing board effectiveness. Corporate Governance. An International Review. 12(4), 442-460. https://doi.org/10.1111/j.1467-8683.2004.00386.x

Petrovic, J. (2008). Unlocking the role of a board director: A review of the literature. 
Management Decision, 46(9), 1373-1392. https://doi.org/10.1108/00251740810911993

Preacher, K. (2017). Calculation for the Sobel test: An interactive calculation tool for mediation tests. Retrieved from http://quantpsy.org/sobel/sobel.htm

Saunders, M., Lewis, P., \& Thornhill, A. (2012). Research methods for business students (5th Ed.). Essex : Pearson Education Limited.

Shleifer, A., \& Vishny, R. (1997). A survey of corporate governance. Journal of Finance, LII(2), 1131-50. https://doi.org/10.1111/j.1540-6261.1997.tb04820.x

Solomon, Jill. (2013). Corporate Governance and Accountability (4th Ed.). John Wiley \& Sons.

Sosik, J. J., \& Jung, D. I. (2002). Work-Group Characteristics and Performance in Collectivistic and Individualistic Cultures. The Journal of Social Psychology, 142(1), 5-23. https://doi.org/10.1080/00224540209603881

Taras, V., Kirkman, B. L., \& Steel, P. (2010). Examining the Impact of Culture's Consequences: A Three Decade, Multi-Level, Meta-Analytic Review of Hofstede's Cultural Value Dimensions. Journal of Applied Psychology, 95(3), 405-439. https://doi.org/10.1037/a0018938

Thomsen, S., \& Conyon, M. (2012). Corporate Governance: Mechanisms and Systems. McGraw-Hill Higher Education.

Triandis, H. C. (2000). Culture and conflict. International Journal of Psychology, 35, 145-152. https://doi.org/10.1080/002075900399448

Tsui, A. S., Nifadkar, S. S., \& Ou, A. Y. (2007). Cross-national, cross-cultural organizational behavior research: Advances, gaps and recommendations. Journal of Management, 33, 426-478. https://doi.org/10.1177/0149206307300818

Van den Heuvel, J., Van Gils, A., \& Voordeckers, W. (2006). Board roles in small and medium-sized family businesses: performance and importance. Corporate Governance: An International Review, 467-485. https://doi.org/10.1111/j.1467-8683.2006.00519.x

Van Ees, H., Van der Laan, G., \& Postma, T. J. B. M. (2008). Effective board behavior in The Netherlands. European Management Journal, 26(2), 84-93. https://doi.org/10.1016/j.emj.2008.01.002

Wageman, R. (1995, April), Interdependence and Group Effectiveness. Administrative Science Quarterly, 40(1), 145-180. https://doi.org/10.2307/2393703

Wan, W. P., \& Hoskisson, R. E. (2003). Home country environments, corporate diversification strategies, and firm performance. Academy of Management Journal, 46(1), 27-45. https://doi.org/10.5465/30040674

Wang, D., \& Ong, C.H. (2005). Board structure, process and performance: evidence from 
public-listed companies in Singapore. Corporate Governance: An International Review, 13(2), 277-290. https://doi.org/10.1111/j.1467-8683.2005.00422.x

World Economic Forum (WEF, 2017). Global Competitiveness Report 2016-2017; Date of data collection or release: 1st September 2017. Retrieved from www.weforum.org/gcr

Yermack, D. (1996). Higher market valuation of companies with a small board of directors. Journal of Financial Economics, 40(2), 185-211. https://doi.org/10.1016/0304-405X(95)00844-5

Zahra S. A., \& Pearce J. A. (1989). Boards of directors and corporate financial performance: a review and integrative model. Journal of Management 15(2), 291-334. https://doi.org/10.1177/014920638901500208

Zona, F., \& Zattoni, A. (2007). Beyond the black box of demography: board processes and task effectiveness within Italian firms. Corporate Governance: An International Review, 15(5), 852-864. https://doi.org/10.1111/j.1467-8683.2007.00606.x

\section{Copyright Disclaimer}

Copyright for this article is retained by the author(s), with first publication rights granted to the journal.

This is an open-access article distributed under the terms and conditions of the Creative Commons Attribution license (http://creativecommons.org/licenses/by/3.0/). 